\title{
10. Gender Mainstreaming and Local Politics: Women, Women's Associations and Mining in Lihir
}

\section{SUSAN R. HEMER}

\section{Introduction}

In 2004, Lihirian women staged a silent protest march in Londolovit town with banners calling for greater involvement in discussions surrounding the review of the agreement (integrated benefits package) between the operators of the Lihir gold mine and the local community. They presented the chairman of the review committee with a petition arguing that women had been left out of 'all aspects of the planning, decision-making and programming for development issues' (Lihir i Lamel 2004: 5). This protest was led by the Petztorme Women's Association, and was unprecedented in the history of Lihir. In part, this chapter aims to understand the strategies that have been employed by women's associations in Lihir to advance the position of Lihirian women and to call for greater political representation, and to appreciate why some have been more successful than others.

The Lihir gold mine, operated by Newcrest Mining Ltd, is located on the main island of the Lihir group of islands in New Ireland Province, Papua New Guinea (PNG). Construction began in 1995, and production in 1997. At the time of writing, active mining was set to continue until 2031, with production from stockpiles for a further ten years or so. 
Annual production has been in the realm of 600,000 to 800,000 ounces. Prior to mining, the Lihir Islands were home to 7,000 Lihirians, whose livelihoods consisted of subsistence production and a small amount of income from cash crops and remittances. Since mining began, the population has grown to include some 16,000 Lihirians, about 4,000 informal migrants, and a further 4,000 migrant employees of the mine and its contractor companies. Vast changes have occurred on the islands, including the construction of a township and a ring road, a medical centre and improved education facilities, as well as increased consumption of alcohol and store-bought goods.

It is unsurprising that with these changes there have been both positive and negative impacts on men and women, and on the relationships between them. Briefly, both men and women have benefited from greater access to health, education and transportation services in Lihir. Paid work is now available for many on the island group through the mining company or its contractors, though this is dominated by men, particularly in more senior roles. Money has also become available through the payment of compensation and royalties, largely paid to men, but onward distribution of this money through lineages has been problematic, and women rarely have any access to it. With money, alcohol consumption has increased dramatically, leading to increases in violence, including domestic violence, and to motor vehicle accidents. Women continue to bear a heavy load of subsistence agriculture, child-rearing and household work, and this remains the case even when women have paid employment. It is mostly Lihirian men who have moved into positions of authority in negotiations with the mining company, who have positions in the locallevel government (LLG), the Lihir Mining Area Landowner's Association and village development committees, as well as being the ones much more likely to hold more highly paying positions in the mining company, to have their own business or to be on the boards of businesses (Macintyre 2003a; Bainton 2010; Hemer 2013).

Two women's associations on Lihir, Petztorme and Tutorme, have aimed to improve the position of women, but have developed quite different strategies to do so. Petztorme has drawn upon international understandings and conventions on gender and development to work for women's development at the international, national and local level, and to argue for greater representation in local-level politics and decision making. Tutorme, on the other hand, has remained focused on the local level and has gained support from both the LLG and the company managing the 
mine. Through an analysis of this case, I argue that gender mainstreaming has not been effective at the local level in Lihir, and that instead women continue to gain their status from their role as guardians of the future through children, youth and health. I begin with an analysis of the broader framework of literature on gender and mining to contextualise the Lihir case.

\section{Gender and Mining}

Male domination of the mining industry around the world is well documented, and the Pacific is no exception. In recent years, however, a number of studies have demonstrated and discussed women's involvement in the industry, with a key aim being to challenge the hegemonic notion of mining as masculine (e.g. Eveline and Booth 2002; Gier and Mercier 2006; Lahiri-Dutt and Macintyre 2006; Moretti 2006; Lahiri-Dutt and Robinson 2008; Lahiri-Dutt 2012).

Mining has also been characterised by its negative impacts, particularly on women. Oxfam Australia (2009) notes that the impacts of mining are not gender neutral. There is a great deal of literature that describes and analyses the impacts of mining on women as miners, as wives and as community members. Women have often been excluded from employment or, as miners, have suffered from poor working conditions, less pay and fewer opportunities for advancement than men (Lahiri-Dutt and Robinson 2008; Sharma 2010). Mining has also been discussed in terms of its negative impact on women's psychological well-being as wives and mothers, in terms of isolation from friends and family in remote locations (Sharma 2010), and also on family life through long working hours and shift work (Chase 2001). As community members, women have been viewed as bearing the brunt of the negative impacts of mining, with little input to negotiations between mining companies and local communities. In the Melanesian context, women have little say in negotiations or control over the compensation that flows into communities (Byford 2002; Macintyre 2002; Oxfam Australia 2009; Wainetti 2013). While Scheyvens and Lagisa (1998) aim to show how women resist mining and logging activities, their paper documents much more thoroughly the lack of empowerment in economic, social, psychological and political domains in regard to mining in Lihir and logging in Solomon Islands, than the ways in which women resist these activities. 
It is in the context of these negative impacts that there have been calls for gender mainstreaming in mining. Gender mainstreaming is the 'process of assessing the implications for women and men of any planned action, including legislation, policies and programmes in all areas and at all levels ... [so that] women and men benefit equally and inequality is not perpetuated' (UN 1997: 27). Lahiri-Dutt (2006) has argued that gender mainstreaming is the right direction for mining projects, yet there have also been critiques of the concept, arguing that women face structural disadvantages that gender mainstreaming is unable to overcome. The common approach is still to add women as a concern rather than have gender as an integral part of planning and processes. As Macintyre (2011: 30) states:

Whatever gender mainstreaming might be in academic terms, by the time it gets into aid projects or workplace policies it has become 'add women and stir' with nobody prepared to actually do this.

There are concerns that 'gender mainstreaming', with its emphasis on 'gender', draws the focus away from women's specific disadvantages (O’Neill 2004; Macintyre 2011). Moreover, it has been suggested that mainstreaming universalises notions of gender that can disempower women even further (Rimoldi 2011).

In recent years, a number of analyses have begun to document and move beyond the 'negative impacts of mining' to understand women as agents who can strategically draw upon mining to improve their lives. Mahy (2011) aims to move beyond the dichotomous representations of women as either indigenous blameless victims of their husbands' sexuality in mining areas or as blameworthy migrant sex workers, to understand the livelihood choices and strategies of sex workers and community women. Lahiri-Dutt (2012) seeks to understand women's agency in mining, whether this be in terms of how women draw upon mining as one of a number of livelihood strategies, or how they act as political agents in protests around mining. Lahiri-Dutt argues that there is a need to appreciate the enormous evidence of women's agency-in their productive roles in mines and at home, and in their resistance to exploitations of mining' (2012: 193). It is these differing forms of strategy and agency — the ways in which Lihirian women are actively navigating local politics to position themselves to benefit from mining - that I explore in this paper. In what ways have they succeeded and how are they positioned as a result? 


\section{Petztorme and Tutorme: A Tale of Two Associations}

Early in the history of the Lihir gold mine there was recognition of the need for an overarching women's association to provide a forum for women's participation in decision making and development programs. So in 1991, with the assistance of the mining company's community relations department and a female consultant, Suzy Bonnell, the Petztorme Women's Association was formed (Membup 2003). Petztorme, meaning 'work together' in the local language, was founded on the church structures of the Katolik Mamas ('Catholic Mothers') and United Church Women's Fellowship already in place in Lihir (Membup and Macintyre 2000). The majority of Lihir villages are predominantly Catholic, with seven United Church villages and a handful of other denominations present in the islands (Hemer 2011). Each village in the island group had its own women's group, with a president, vice-president, secretary and treasurer. The Petztorme executive mirrored this structure, with a president, vicepresident, secretary and treasurer and the presidents of the women's groups in the four local churches (Catholic, United, Pentecostal and Seventh-Day Adventist). Petztorme also had a general council comprising representatives of each council ward on Lihir. ${ }^{1}$

Since 2014, Petztorme has altered its structure to require financial membership rather than simply encompassing all women on Lihir. Groups of 5-20 women choose to become financial members of Petztorme by paying a small fee (K50 in 2014). There were 35 member groups in 2014, from nine of the 15 council wards. This financial membership seems to promote more active presence and membership at meetings, and more engagement with the programs of the association.

In the early years of mining, Petztorme worked with women who were being relocated from two villages in order to allow mining to go ahead. It also began a number of income-generating projects: a nursery, market and can crusher in order to provide incremental self-help development for women. The difficulties with this approach, and the sectarian divisions in the association, have been well documented by Macintyre (2003b), who argues that most women's projects in PNG fail due to issues with leadership once external advisers or funders withdraw.

1 Lihir is divided into 15 wards for the purpose of the local government council system. Most wards comprise two or three villages. 
By 2000, when I began work in the mining company's community relations department, Petztorme was still being supported by the 'women's section' of this department to successfully undertake a number of projects and programs with local women. While the nursery and can crusher had failed, the market was still functional, and was earning Petztorme a good ongoing revenue. It was at this time that a new project began, emerging out of a cultural exchange program between expatriate and Lihirian women, and the desire for training in sewing skills. A training centre was set up, with an expatriate seamstress able to train Lihirian women in sewing skills (see Hemer 2016; Macintyre 2003b).

This training centre came to be known as the Tutorme Training and Sewing Centre, and functioned out of a small building provided by the mining company. ${ }^{2}$ It was managed by an advisory committee of expatriate and Lihirian women, including myself as secretary. The seamstress became the key trainer, with her salary provided by the mining company as well. Sewing training was taken up with gusto, with some 200 women paying to take classes in sewing by 2002. Many had completed a full sequence of training, and a select number had found employment with Tutorme. In 2001, Tutorme moved to a new building, once again provided by the mining company, and had taken on a number of commercial sewing projects, such as providing curtains for dormitories and embroidering company logos on uniforms. It was also during this year that Tutorme was registered as an association, much to the concern of Petztorme women, who argued that having two associations for women in Lihir was likely to be a source of confusion and friction.

Even at this early stage, sectarian divisions within the two associations, as well as between them, threatened the continued viability of Tutorme. In 2002, the mining company provided Petztorme with a building of its own, at least partially to placate the Petztorme executive members who were critical of their lack of input into the direction in which Tutorme was heading. While this temporarily appeased most women, and provided a much-needed office space within the township, tensions between Tutorme, now managed through a financial advisory committee heavily composed of expatriates, and the Petztorme executive continued.

2 Tutorme means 'stand together' (tu torme), rather than 'tutor me'. 
From 2002, Tutorme continued for some time as a relatively successful sewing centre. Then, with the departure of the expatriate manager in 2005 , its continued viability was threatened. In about 2008 , the building that housed Tutorme was condemned and, while the sewing machines remained onsite and the intention was to relocate these to a new building, in reality Tutorme as a sewing centre is now defunct. This building has since been refurbished for use as a general conference and meeting space, and named the Lihir Meri Developmen Senta ('Lihir Women's Development Centre'). Its use is not restricted to any particular women's group, or to women in general, though any revenue from use of the centre is allocated to women.

In 2009, Tutorme re-emerged on the Lihir scene as the Lihir Tutorme Women's Association, a general women's association working for women's development. This re-emergence was in response to concerns in the mid2000s about the lack of programs for Lihirian women, and Petztorme's lack of financial transparency. There was a failed attempt to change the executive committee of Petztorme, and eventually it was decided to bypass it by creating a new association.

\section{Local Initiatives in Women's Development}

Both Tutorme and Petztorme have run a number of successful initiatives on Lihir. In its new incarnation Tutorme has been functional for a number of years, and in that time has focused on education and awareness programs for women and youth in villages, covering topics such as law and order issues, education and adult literacy. One of its recent programs was to hire a theatre group to provide entertaining and engaging education on HIV/ AIDS. Tutorme has drawn upon the Nimamar Rural LLG, links with the mining company (formerly Lihir Gold Limited, now Newcrest), and the Lihir Sustainable Development Plan (LSDP), ${ }^{3}$ both for small annual budgets and for material assistance and transport to implement these initiatives.

3 The LSDP arose out of the review of the integrated benefits package, the agreement between the Lihir community and the mining company which specifies the benefits to be provided to Lihirians on a five-yearly cycle. The LSDP is a plan for the development of Lihir using mining revenue, and is also an organisation with a budget to carry out that plan. 
Petztorme has also been involved in women's health programs in Lihir. In the early 2000s, the association was a key partner and supporter of initiatives by the Lihir Medical Centre and the mining company's women's section as they carried out programs on nutrition in villages around the island group. Petztorme was also heavily involved in supporting the programs of the medical centre's maternal and child health clinic, including the key nurse in her work on family planning. There were concerns in the early 2000s about population and family planning issues, and Petztorme organised and supported a workshop on this issue, with Petztorme members taking information back to their village groups. This interest in health has continued since that time, and programs on healthy families and villages were scheduled for 2014 .

Petztorme continued to manage the market in the township until its 'temporary closure' in 2011, and this provided a source of revenue to fund more projects. ${ }^{4}$ In late 2003 , it launched a women's microcredit scheme with loans of K500-700 charging 10 per cent interest and, in 2004 , employed a woman to coordinate this project. This seems to have been problematic, however, as the credit scheme was halted in 2005 and had not been relaunched at the time of writing. Also in 2004, Petztorme was successful in gaining grants from the LLG of K10,000 per ward for women's projects, hence a total of K150,000. This money was to be used for vegetable gardens, bakeries, vanilla plants and small market houses to provide ongoing sources of money to women in villages. More recently, Petztorme has provided a route for providing information to women about financial opportunities provided by organisations like the New Ireland Savings and Loan Society and the Nationwide Microbank, and more generally on financial management and literacy.

On a more political note, in the early 2000s Petztorme pushed for women's representation in local government, leading to the appointment of two women's representatives to the Nimamar Rural LLG. This LLG is made up of 15 elected members, one each for the 15 wards in Lihir. The two female representatives are additional to this body, and were chosen by Petztorme to be the conduit for women's views to be taken to the LLG and for information from the government to be brought back to Petztorme

4 The temporary closure came about due to concerns over the cleanliness of the market and continued upkeep of the area, as well as debates over the position of migrants selling goods at the market and forcing prices too high. While 'temporary', it proved very difficult to resolve these issues and the market was closed for at least 12 months. 
and hence to Lihir village women. Also, as noted at the beginning of the chapter, Petztorme successfully lobbied for the inclusion of women in negotiations between the community and the mining company, and an additional woman was added to the Joint Negotiating Committee in the 2000-07 negotiations to bring the total to two. However, in the more recent negotiations beginning in 2012, Lihirian women have again struggled to get representation on the Joint Negotiating Committee despite Petztorme executives asking for this. In this respect, it can be seen that Petztorme has been more overtly concerned than Tutorme with the processes of local politics.

The initiatives of Petztorme and Tutorme at the local level have generally focused on aspects of everyday life understood as key concerns for women. These include gardening, cooking and sewing, and sometimes the sale of fruit and vegetables, or cooked food and sewn items, to make small amounts of money. Health is also seen as another key concern for women, as it is women who oversee the health and nutritional needs of their families. However, the claims by Petztorme for greater involvement and representation in local politics and negotiations signal a more global understanding of gender relations.

\section{Petztorme: Going National and Global}

In the two decades since the inception of Petztorme, the association has begun to choose to work beyond the local arena of Lihir. At the national level, members of Petztorme participated in the two 'women in mining' conferences held in Madang in 2003 and 2005 and spoke about the experiences of Lihirian women (Membup 2003). Petztorme has also provided a link between initiatives at the national level and women in Lihir. Members of Petztorme attended information sessions in Port Moresby about small grants from the United Nations Development Programme (on climate change and the environment) and the Women in Mining National Action Plan, then conveyed what they learned to women in Lihir, and planned to apply for grants under these programs.

One member whom I shall call Mary has also been sponsored by the Centre for Environmental Research and Development (CERD), a PNG non-governmental organisation largely funded by Oxfam Australia, to be a member of the Mine Affected Women's Foundation. Mary was able to attend the 2005 women in mining conference, as well as the 2007 
Pacific women and mining conference (Oxfam Australia 2009), and was a signatory to the 2007 declaration by CERD opposing any new mines in PNG. Mary has also been able to raise Lihirian women's concerns over mining at a global level through overseas travel, interviews and publications. In 2003, she travelled to Portugal for a meeting of the World Bank's Extractive Industries Review, as well as making a written submission to it in 2004. Mary also travelled to London to raise environmental concerns at Rio Tinto's annual general meeting in 2003, when Rio Tinto still had a controlling interest in the Lihir mine. She was interviewed by Friends of the Earth International, and her comments about environmental disruption in Lihir are recorded in a 2003 publication as well as on their website. $^{5}$

One Petztorme executive member is also the co-author of a chapter in an internationally published book that documents concern about the social and environmental risks of large-scale mining projects (Moody 2005). The Petztorme executive as a whole has been active and able to raise Lihirian women's concerns about the impacts of mining on Lihirian women and youth in particular, and also on the Lihirian environment, to national and global levels. At the national level in PNG, understandings of women in mining have been shaped by global discourses on gender.

\section{Gender Mainstreaming and the National Action Plan}

The PNG Government developed its Women in Mining National Action Plan as a result of national conferences on 'women in mining' held in 2003 and 2005 (GoPNG 2007). These conferences were themselves part of an institutional strengthening project funded by the World Bank. The aim of the National Action Plan is to draw attention to the issues affecting women in mining areas in the country, and to then set the direction for addressing these issues. The plan draws upon key international conventions and obligations including the Millennium Development Goals, the Beijing Declaration, and the Convention on the Elimination of All Forms of Discrimination against Women. In this respect, it highlights

5 In order to maintain confidentiality, I am not including the reference for these comments here. 
the importance of gender mainstreaming for the PNG Government in aiming to achieve women's empowerment and equality. As outlined in the National Action Plan, gender mainstreaming in mining is the:

equitable distribution of the resources, opportunities and benefits of the development process and addresses gender inequalities in the mainstream of organizational policies, plans and programs, not just as separate, ad-hoc activities (GoPNG 2007: 3).

There is a clear recognition, then, that gender mainstreaming in mining aims to move beyond approaches that simply add a recognition of women to supposedly neutral plans and programs.

The National Action Plan lists eight goals which are, very briefly, to raise women's education and literacy; to improve access to reproductive health services; to prevent or control communicable diseases, including tuberculosis and sexually transmitted infections; to increase women's participation in economic, political, cultural and social life; to ensure that women's associations function beyond mine closure; to ensure sustainable livelihoods; to mitigate or avoid environmental degradation; and to promote security and peace in communities. Each of these goals has related objectives, strategies and targets. Many of these involve awareness raising, and numbered or named targets such as, for example, a certain number of training sessions held, water tanks at six health facilities, or 10 per cent of women multiskilled by 2012. It is clear that such an ambitious plan would require high-level coordination, and this is acknowledged in the implementation framework, yet there is little discussion of how this would actually occur.

The plan acknowledges that women should be involved 'in the development of policies, design and management of programs at all stages and levels of decision making' (GoPNG 2007: 3). This then becomes part of the fourth goal of the plan, which is to increase women's participation in the economic, political, cultural and social life of their communities. One of the objectives of this goal is for women's participation in local political processes, such as landowner associations and mine closure committees, as well as in employment. This is one of the few goals that have an objective that aims for equality, such as 50 per cent participation in landowner associations. Most of the objectives, even in this goal, aim for an addition of women to existing committees, or for awareness raising and 'gender 
sensitivity' amongst males. Yet once again there is little discussion in the plan of how participation of women in local political processes will be achieved, other than by awareness and sensitivity training.

Most of the goals in the plan, despite its acknowledged context, have little to do with gender mainstreaming and equality, whether this be in education, health or agriculture. Most of the targets (such as a 50 per cent increase in female student enrolment) are set without any discussion of the communities' needs and strengths prior to the plan, which would vary between the different mine sites around the country. Overall, the aim of the plan is for improvements to the current conditions that women face, rather than for gender mainstreaming or equality.

There is little evidence of the National Action Plan having any impact in Lihir. Despite the number of Lihirian women attending the women in mining conferences, no one I spoke to in 2011, 2012 or 2014 mentioned the existence of the plan. One of the leaders of Tutorme did say that their emphasis on awareness programs arose out of one of the conferences, which was possibly a reference to the plan, since awareness programs were a key feature of the activities listed in it. Yet there is no explicit discussion of the plan itself. This suggests at the least that women are unlikely to be using the plan to leverage changes in Lihir. Of the eight goals mentioned in the plan, some were already being pursued, funded and organised through relevant organisations such as the Lihir Medical Centre or the LLG, but no one carrying out these activities seemed to be aware that they were fulfilling the goals of the National Action Plan, so it seems quite likely that the goals were being pursued by accident rather than by design.

There were few calls for gender mainstreaming in Lihir. Where there was some activism was in terms of calls for some level of representation for women in local politics and on bodies negotiating over the benefits of mining, as noted at the beginning of this chapter. More recent years have seen sustained activism against gender violence. Women also called for more business opportunities and for the need for access to sources of funding. In the realm of employment there was little activism around equity of access or rates of pay. ${ }^{6}$ The ways these issues became part of local practice, however, was in terms of adding women in to existing

6 Where there was activism in relation to employment, it tended to be in terms of Lihirians' access to employment and conditions relative to other Papua New Guineans, rather than being concerned with differences between men and women. 
processes — the 'add women and stir' approach (Macintyre 2011: 30) — rather than significantly challenging the processes or practices themselves. Hence more global notions of gender mainstreaming and equality had little currency in Lihir, where other understandings of gender relationships held sway-in particular, relationships between men and women based in nurturance, respect and work.

\section{Women's Status in Lihir: Sio, Ertnin and Pniez}

Lihirians are members of both lineages and named clans with matrilineal descent. Land tenure is said to be based on matrilineal inheritance, but is complex and has cognatic tendencies. As argued by Macintyre (2003b), in pre-colonial times it is unlikely that women participated in exchanges in their own right, and even today they assert little control over land or ritual events. Despite this, a woman could develop the reputation and status of a 'big woman' (wok tohe) on rare occasions, and more commonly it was known that the renown of 'big men' (a tohe) rested largely upon their wives and sisters (Bainton 2010: 83-5).

Women's status is best understood through the concept of sio, meaning the respect shown to someone or that someone has earned. Sio is most commonly used in reference to big men, to indicate that people respect them by demonstrating respectful behaviour and providing them with shell money $(a l e)$ with which they could participate in exchanges. Thus the respect shown to a big man would allow for the further development of the reputation of the clan through ritual exchanges.

Women did not receive sio in the form of shell money, but gained it through the bearing and raising of children, and through the production of garden food and pigs that could be exchanged for shell money. The key term used to refer to these processes is ertnin, a term that indicates a productive future-oriented practice, often meaning nurturance (Hemer 2013). Hence a woman would carefully nurture her children, gardens and pigs. As a mother she would aim to have many children, but space them carefully so they would all grow to healthy maturity. A woman who was highly productive, with large gardens full of yams and pigs grown fat to adulthood was one who was highly valued by her husband, and one who could inspire the jealousy of her husband's male rivals. Sometimes she would be the subject of sorcery attacks intended to inhibit her capacities. Such a woman was one of high status_-one who had earned sio. 
Sio was also demonstrated through appropriate behaviour between classes of kin. For example, sisters were understood to be mutually supportive. A brother and sister should not speak of sexual matters in one another's presence, nor should a sister walk past her sleeping brother's head. Male and female cross-cousins should refrain from using each other's names, but were expected to joke. Male cross-cousins were expected to have a highly supportive relationship that was not the site for jealousy or anger. It was understood that often behaviour did not necessarily meet these ideals, and was the focus for angry confrontations and relationship tension. Yet conformity with these expectations was a demonstration and practice of respect, and in itself could earn respect. Many of these expectations underpin both the practice of gender relations and the interpretation of appropriate and respectful conduct.

While it is understood that both benefits and respect can be gained either through hard work or through positions or associations, women generally gained their sio not through their positions or associations, but through their own hard work (pniez). In the context of mining there has been some backlash against benefits received through positions, like the royalties gained by a person as a member of a particular lineage. This backlash is particularly strong where these royalties are then not distributed throughout the lineage, as it seems that the receipt of these benefits relies on relational qualities that are simultaneously denied. This has meant that the moral value of pniez as the source of benefits has become more acutely understood. This point is key to understanding the criticisms made of some Lihirian women.

\section{Women's Associations and Women's Status}

In order to carry out many of its programs, Petztorme has drawn upon Lihir women's voluntary labour. This has been one of the weak points of the organisation, in the sense that Lihirian women already have many other things that draw upon their time. As many men and young women have gained employment with the mine, the volume of work carried out by village women has increased, meaning that there is even less time available for voluntary communal work (Macintyre 2003b). Given that much of the work for Petztorme drew upon existing skills and understandings of women's work, such as growing plants or vegetables for sale or providing health and nutrition information, it has not been the basis for gaining additional respect nor a source of challenge to conventional notions of 
women's status. Although it constitutes an extra obligation for women who are already very busy, this work at the local level has still been seen as generally appropriate for women.

Similarly, Tutorme in its first incarnation extended this understanding of appropriate women's activities through its sewing training. Most of the women who sought training were able to use these skills to provide for their families in the village setting: only a handful went on to gain employment with Tutorme. For those who did, like women who work for the mine, their earnings are expected to be used to provide for their immediate family or for the customary work and feasting of their lineage. The new incarnation of Tutorme likewise draws upon women's time and work to provide further awareness and health education for women and youth in the village. At this local level, then, the strategies of both Petztorme and Tutorme confirm and bolster women's status based in their work and the nurturance of families, gardens and pigs.

The activities of Petztorme at the national and global level were perceived quite differently. For most women, the travels of women like Mary or other executives of Petztorme were seen not as working for the broader benefit of Lihirian women. Rather, these were seen as a personal benefit - a chance for them to experience the wider world and gain a name for themselves. Their efforts to raise the concerns of Lihirian women at the national and international levels, and their experience with government and non-governmental organisations, have not translated to additional sio for them at the local level. While the ability to speak up about the concerns of women, particularly in front of men, is valued by other women, it is generally not highly valued by Lihirian men, and does not appear to be a source of sio. Mary, for example, has instead been the subject of much criticism about 'doing nothing' for Lihirians while benefiting from her position in the Petztorme executive. Her actions are not perceived as morally valued work. Thus Mary has been caught in the disjunction between national and global discourses on gender and mining on the one hand, and local Lihirian notions of the appropriate work and place of women on the other.

The existence of two women's associations, and divisions both within and between them, has been a continual focus of criticism on the part of Lihirian men. Men have continually pointed to the mismanagement (or lack of management) of programs, equipment and buildings as evidence of Lihirian women's inability to work cooperatively or organise development 
initiatives. There has been ongoing insistence that Lihirian women need to develop 'one voice' before they should seek to have an input to negotiations over benefits from the mine. Lihirian women have largely accepted this insistence and justification for their lack of representation in local political and economic matters, and have continually attempted to develop models for reconciliation or cooperation. This was ongoing even as recently as 2016, with men insisting that women reconcile to have 'one voice' in order to contribute to the agreement review process, and women concurring. There is often little reflection by women on the lack of cooperation among men or among the various groups that represent them. There is also very little comment on the different conditions for other associations, often with almost exclusively male membership, which do not rely on voluntary labour. These include the Nimamar Rural LLG and the Lihir Mining Area Landowners' Association, in which men are salaried, and the boards of various businesses that pay men but require little work. Thus far, the differences among women's groups have proven too difficult to resolve despite lengthy efforts to achieve reconciliation, and women remain largely excluded from local politics and decision making.

\section{Lihir Women's Status and Gender Mainstreaming}

In a context where value is placed upon women's nurturance of children, gardens and pigs, gender mainstreaming can appear as a threat to these traditional sources of status. Women, through Petztorme and Tutorme, have appealed to other women, and to both expatriate and local Lihirian males, in their roles as guardians of the future to effect changes at the local level. This has been an effective strategy in gaining acceptance of programs about health or sewing, to make changes at the market run by Petztorme, or to call for changes to the sale of alcohol. Such activities fit well with the broader understanding of women's position and positively contribute to their status or standing (sio). In particular, Lihirian men have been supportive of such approaches, and hence there has been funding support for programs such as these by the Nimamar Rural LLG and the Lihir Sustainable Development Plan.

Yet when Lihirian women aim or argue for greater access or representation, particularly in the realms of politics and employment, they undercut those understandings of women's status. Instead, women then become 
the subject of criticism and jealousy from other women as they are seen to be benefiting themselves rather than performing morally valued work. It also appears that, as they draw less upon those nurturance roles, they have to build their status in new ways. This roughly translates as being seen to be 'doing something', often in various forms of leadership, which may include proposing and organising successful meetings, training opportunities and projects from which Lihirian women can benefit. Yet such a definition of success in raising their status leaves them open to criticism similar to that which many Lihirian men also face. Thus Mary and other members of the Petztorme executive over the past ten years have been subject to charges of misuse of funds or association property, and of responsibility for a lack of real development for Lihirian women. As argued by Macintyre (2003b), the local model of successful leadership is one where leaders must distribute largesse; if they are unable to do so then their leadership, and hence their standing in the community, is contested.

If gender mainstreaming, as defined internationally, implies that women should be the equals of men in their access to employment, politics, and hence sources of status, then such a model can be problematic in a country such as PNG. Rimoldi has pointed out the danger in a discussion of the Leitana Nehan Women's Development Agency in Bougainville:

By taking on the vocabulary and orientation of international development or welfare agencies (and affiliating with them), this once very grassroots organisation gradually came to believe that it was dependent on aid money for existence. In a sense it looks like a 'buy out' of women's influence and authority intrinsic to their traditional standing in Bougainville society. (Rimoldi 2011: 191)

Rimoldi goes on to question what precisely 'mainstream' means, and how gender in Bougainville may be shaped in response to these international concerns (ibid.: 191-2).

Onyeke has argued, in the context of PNG, that it is necessary to go beyond notions of equality to aim more broadly for respect:

[T] he idea of using political or leadership gender equality to measure the value and dignity of PNG women is far too simplistic and overly optimistic (Onyeke 2010: 12).

This respect should be based on the dignity of the person rather than due to their roles or achievements. This accords with Walby's (2005) argument that, where gender mainstreaming implies women gaining equality on 
terms set by male norms, there is a risk that women's sources of authority can be undermined. This is clearly the case for Lihir, where a woman's status continues to be tied to her capacity to contribute through the nurturance of children, gardens and pigs, and in a lesser way through the contribution of her earnings to her family and lineage. Similarly for Onyeke, mothering - and by extension the 'social act of caring and nurturing' - should be the model and basis for respect of women (Onyeke 2010: 13). It is possible that these activities of nurturance may come to be understood as of lesser value by Lihirian men and women if arguments for equality become more commonplace in Lihir.

\section{Conclusion}

In moving away from analyses that emphasise the negative impacts of mining on women, it is possible to productively examine the strategies and choices made by women in the context of mining developments. The two women's associations on Lihir have followed different strategies in an attempt to advance women's positions: both Tutorme and Petztorme emphasise traditional forms of women's status, yet Petztorme has appealed to a broader audience and more global understandings of gender and mining. Strategies adopted at the local level by both associations have aimed to consolidate and strengthen traditional sources of women's status through work on the nurturance of children and youth, with attention to human health and a productive environment. Yet such a focus does little to challenge Lihir women's position relative to men and their lack of local political representation, as well as the real conditions of disadvantage that they face.

Petztorme's efforts at the national and global levels to raise the concerns of Lihirian women about the impact of mining, and to call for a place in local political representation and decision making, clearly resonate with some of the aims for equality and access that characterise gender mainstreaming. To date their claims fall well short of the 'equitable distribution of resources, opportunities and benefits', and equal participation in policies, plans and programs, that are core to gender mainstreaming (GoPNG 2007: 3). Even in this partial form, the strategies of Petztorme have not been met with much enthusiasm or acclaim on Lihir, and speak to the difficulty of improving the conditions for women and their representation in local political processes. 
At present, it is uncertain how successful each of the strategies adopted by Lihirian women's associations will be. It may well be the case that the strategy of Tutorme, which places greater emphasis on the nurturing roles of women, will be much more successful in this local context. Rather than directly challenging men and arguing for equality, it highlights the strengths of the unique contributions that women can make to social life. Yet it is clear that women should have a voice and a place at the negotiation table, as well as equitable access to any opportunities and benefits afforded by mining within their community. It would appear that gender mainstreaming, as understood at the national and international levels, is unlikely to prove to be a workable model, at least for Lihirian women. To judge by the local perception of Petztorme's efforts at the national and global levels, it is quite possible that their strategy may work against Lihirian women in the long run by undercutting their traditional sources of status, which would place them at an even greater disadvantage.

\section{References}

Bainton, N.A., 2010. The Libir Destiny: Cultural Responses to Mining in Melanesia. Canberra: ANU E Press (Asia-Pacific Environment Monograph 5).

Byford, J., 2002. 'One Day Rich: Community Perceptions of the Impact of the Placer Dome Gold Mine, Misima Island, Papua New Guinea.' In I. Macdonald and C. Rowland (eds), Tunnel Vision: Women, Mining and Communities. Fitzroy: Oxfam Community Aid Abroad.

Chase, J., 2001. 'In the Valley of the Sweet Mother: Gendered Metaphors, Domestic Lives and Reproduction under a Brazilian State Mining Company.' Gender, Place and Culture 8: 169-187. doi.org/ 10.1080/09663690120050779

Eveline, J. and M. Booth, 2002. 'Gender and Sexuality in Discourses of Managerial Control: The Case of Women Miners.' Gender, Work and Organization 9: 556-578. doi.org/10.1111/1468-0432.00175

Gier, J. and L. Mercier, 2006. Mining Women: Gender in the Development of a Global Industry, 1670-2005. New York: Palgrave Macmillan. doi.org/10.1007/978-1-349-73399-6 
GoPNG (Government of Papua New Guinea), 2007. Women in Mining National Action Plan 2007-2012. Port Moresby: Department of Mining.

Hemer, S.R., 2011. 'Local, Regional and Worldly Interconnections: The Catholic and United Churches in Lihir, Papua New Guinea.' Asia Pacific Journal of Anthropology 12: 60-73. doi.org/10.1080/144 42213.2010.535844

_ 2013. Tracing the Melanesian Person: Emotions and Relations in Libir. Adelaide: University of Adelaide Press.

— 2016. 'Sensual Feasting: Transforming Spaces and Emotions in Lihir.' In S. Hemer and A. Dundon (eds), Emotions, Senses, Spaces. Adelaide: University of Adelaide Press.

Lahiri-Dutt, K., 2006. 'Mainstreaming Gender in the Mines: Results from an Indonesian Colliery.' Development in Practice 16: 215-221. doi.org/10.1080/09614520600562488

— 2012. 'Digging Women: Towards a New Agenda for Feminist Critiques of Mining.' Gender, Place and Culture 19: 193-212. doi.org/ 10.1080/0966369X.2011.572433

Lahiri-Dutt, K. and M. Macintyre (eds), 2006. Women Miners in Developing Countries: Pit Women and Others. Aldershot: Ashgate.

Lahiri-Dutt, K. and K. Robinson, 2008. "Period Problems" at the Coalface.' Feminist Review 89: 102-121. doi.org/10.1057/fr.2008.5

Lihir i Lamel, 2004. 'The Silent March for Equality.' Unpublished petition.

Macintyre, M., 2002. 'Women and Mining Projects in Papua New Guinea: Problems of Consultation, Representation, and Women's Rights as Citizens.' In I. Macdonald and C. Rowland (eds), Tunnel Vision: Women, Mining and Communities. Fitzroy: Oxfam Community Aid Abroad.

_ 2003a. 'The Changing Value of Women's Work in Lihir.' Paper presented at the conference on 'Women in Mining: Voices for Change', Madang, Papua New Guinea, 3-6 August.

_ 2003b. 'Petztorme Women: Responding to Change in Lihir, Papua New Guinea.' Oceania 74(1-2): 120-133. 
__ 2011. 'Modernity, Gender and Mining: Experiences from Papua New Guinea.' In K. Lahiri-Dutt (ed.), Gendering the Field: Towards Sustainable Livelihoods for Mining Communities. Canberra: ANU E Press (Asia-Pacific Environment Monograph 6).

Mahy, P., 2011. 'Sex Work and Livelihoods: Beyond the "Negative Impacts on Women" in Indonesian Mining.' In K. Lahiri-Dutt (ed.), Gendering the Field: Towards Sustainable Livelihoods for Mining Communities. Canberra: ANU E Press (Asia-Pacific Environment Monograph 6).

Membup, J., 2003. 'The Status of Women Affected by Mining in Lihir.' Paper presented at the conference on 'Women in Mining: Voices for Change', Madang, Papua New Guinea, 3-6 August.

Membup, J. and M. Macintyre, 2000. 'Petzstorme: A Women's Organisation in the Context of a PNG Mining Project.' In B. Douglas (ed.), Women and Governance from the Grassroots in Melanesia. Canberra: The Australian National University, State Society and Governance in Melanesia Program (Discussion Paper 00/2).

Moody, R., 2005. The Risks We Run: Mining, Communities and Political Risk Insurance. Utrecht: International Books.

Moretti, D., 2006. 'The Gender of the Gold: An Ethnographic and Historical Account of Women's Involvement in Artisanal and SmallScale Mining in Mount Kaindi, Papua New Guinea.' Oceania 76: 133-149. doi.org/10.1002/j.1834-4461.2006.tb03041.x

O’Neill, P., 2004. 'Rethinking Gender Mainstreaming (Or, Did We Ditch Women When We Ditched WID?)_A Personal View.' Development Bulletin 64: 45-48.

Onyeke, D., 2010. 'Real Men Don't Hit Women: The Virtue of Respect As a Strategy for Reducing Gender-Based Violence in Papua New Guinea.' Contemporary PNG Studies 13: 1-16.

Oxfam Australia, 2009. 2007 Pacific Women and Mining Conference. Carlton: Oxfam Australia.

Rimoldi, E., 2011. 'Force of Circumstance: Feminist Discourse in a Matrilineal Society.' Asia Pacific Journal of Anthropology 12: 180194. doi.org/10.1080/14442210903289348 
Scheyvens, R., and L. Lagisa, 1998. 'Women, Disempowerment and Resistance: An Analysis of Logging and Mining Activities in the Pacific.' Singapore Journal of Tropical Geography 19: 51-70. doi.org/ 10.1111/j.1467-9493.1998.tb00250.x

Sharma, S., 2010. 'The Impact of Mining on Women: Lessons from the Coal Mining Bowen Basin of Queensland, Australia.' Impact Assessment and Project Appraisal 28: 201-215. doi.org/10.3152/14615 5110X12772982841041

UN (United Nations), 1997. 'General Assembly Fifty-Second Session: Report of the Economic and Social Council for 1997.' Viewed 2 March 2016 at www.un.org/documents/ga/docs/52/plenary/a52-3.htm

Wainetti, U., 2013. 'Responding to Fast Changing Community Aspirations.' Paper presented at the conference on 'Mining for Development', Sydney, 20-21 May.

Walby, S., 2005. 'Gender Mainstreaming: Productive Tensions in Theory and Practice.' Social Politics 12: 321-343. doi.org/10.1093/sp/jxi018 
This text is taken from Large-scale Mines and Local-level Politics: Between New Caledonia and Papua New Guinea, edited by Colin Filer and Pierre-Yves Le Meur, published 2017 by ANU Press, The Australian National University, Canberra, Australia. 